\title{
Long Term Consumption of Ibie Leave (Mucuna Flagellipes) Diets Improves Visuo-Spatial Learning and Memory in Swiss White Mice
}

\author{
Amah $^{1 *}$, AK Aduema W' ${ }^{2}$, Amah UK ${ }^{3}$ and Ejiofo DC ${ }^{1}$ \\ ${ }^{1}$ Department of Medical Physiology, Imo State University, Nigeria \\ ${ }^{2}$ Department of Human Physiology, PAMO, University of Medical Sciences, Nigeria \\ ${ }^{3}$ Department of Chemical Pathology, Nmandi Azikiwe University, Nigeria
}

Received: 棒 June 28, 2018; Published: 眥July 19, 2018

*Corresponding author: Amah, Department of Medical Physiology, Imo State University Department of Human Physiology, PAMO University of Medical Sciences, Nigeria, Email: Wadioniaduema@gmail.com

\begin{abstract}
Mucuna Flagellipes is one of the plants commonly used widely in the South Eastern part of Nigeria for the treatment of Anemia. There have never been any record authenticated to the best of my knowledge that focus on the effect of Mucuna Flagellipes on visuo-spatial learning and memory, therefore the objective of this study was to determine whether Mucuna flagellipes has effect on the above neurobehavioral parameter, using CD-1 as experimental animals. Thirty CD-1 mice were bought and randomly divided into two groups, consisting of ten (10) mice. Group 1 (control) received normal rat fed whereas group 2(test) received the Mucuna diet and clean drinking water for twenty-one days. After this period, they were tested using the Morris water maze. The group 2 animals that received the Mucuna flagellipes showed improved learning and memory behavior by a significantly lower swim latency during acquisition training and reversal training $(\mathrm{P}<0.01)$ and $(\mathrm{P}<0.05)$ compared to group 1 (control). Preference to the Northwest and Southeast quadrant was statistically higher $(\mathrm{P}<0.001)$ compared to group 1 . Annulus reversal crossing was also higher $(\mathrm{P}<0.01)$ when compared to group 1 . In visible platform task, the test group was statistically lower $(\mathrm{P}<0.001)$ compared to group 1 . Therefore, Mucuna Flagellipes with a fair measure of accuracy improves learning and memory and could be used in the management and treatment of retrograde amnesia.
\end{abstract}

Keywords: Mucuna Flagellipes; Morris Water; Maze; Memory; Mice; Amnesia

\section{Introduction}

The system of use of plants for food and drug dates back to the early man on earth [1]. The use of natural products with medicinal properties for chronic and acute diseases is as old as human existence [2] long ago, animal products, plant and mineral are the main sources of medicine $[3,4]$. About $40 \%$ of the population of the technologically and economically advanced countries like the U.S.A, U.K, still makes use of alternative remedies, including herbal medicine for disease prevention and cure [5]. In addition, compounds Plant based medicine has over time become man's prime therapeutic weapon and still is as seen in its continued use in treatment of diseases up till today [6]. All over the world, humans have used a variety of numbers of native plants in the cure of diseases since prehistoric times $[7,8]$. There is hardly any person who does not take herbal remedy daily in one form or the other. This is true as reports by [9] revealed, in anyone who eats vegetables, takes medicinal herbs, be it lettuce and spinach in Sumerians who described well established medicinal plants as laurel caraway and thyme.
Also, the Chinese herbal book dating from about 2,700 BC listed medicinal plants and their uses [10]. Many cultures have used different types of plants or materials derived from them in preventing and treating diseases through history [11]. Its efficacy is justified by its continued use. It is for the development of modem chemistry that has led to the discovery and identification of the materials in plants that serves as drugs or basic material for the synthesis of many important drugs used today. These drugs been synthesized from the knowledge acquired from studies of the mechanism of chemicals and their actions first separated from herbs. Thus, researchers in medicinal herbs have increased in order to ascertain their chemical compositions which are medicinally active. Mucuna flagellipes which is commonly called cow itch and locally called Ibie. There is abundance of macro elements like calcium magnesium and iron [12]. The pod hairs have been used in India to treat snakebite [13] while in West Africa; it is the stem that is used for treating of snakebite [14]. Their stems have been 
reported to also improve sexual potency $[15,13]$. Its pods have also been used to deworm patients [16].

The modus operandi of the pod hair is mechanical, thus when mixed with substances like honey, pierces the bodies of the intestinal worms, twisting such that catharsis will push them out. Although it is seen to have little effect on tape worms $[17,18]$. The leaves supply a proteinous fodder for livestock's while the nodules play an important role in nitrogen fixation in the soil [19-21]. The stem is also used for tying seeds in the bam and yield black dye. The use of Mucuna flagellipes in recent time has been on the increase as a result of its speculated therapeutic effect mostly on the protein level of the body [22]. And owing to the fact that there are no detailed reports on Mucuna flagellipes or from the best of my knowledge any study or report on its effect on learning and memory, this work is therefore intended to determine the effects of this herb on the learning behavior and memory of Swiss white mice.

\section{Animal care}

A total of twenty healthy CD-1 mice weighing 20-22grams were used for the study and the mice were bought from the Department of Pharmacology of Michael Okpara university of Agriculture, Umudike Nigeria. The mice were kept in a clean and well-ventilated compartment and fed with normal rodent fed and allowed access to water ad libitum for fourteen days to allow acclimatization before the commencement of the experiment.

\section{Experimental Design}

Dried pulverized Mucuna flagellipes was mixed with the rodent chew at a proportion of 30 grams of the powdered leave and 70 grams of the rodent chew. The Swiss mice were divided into two groups, namely: Group 1 and Group2. The group 1 was the control which received 50 grams of rodent chew and $60 \mathrm{ml}$ of water daily while the group2 was the test group that received 50grams of the mixed leave and rodent chew, with $60 \mathrm{ml}$ of water daily. Analysis of the phytochemical composition of the leaves of Mucuna flagellipes was done following the methods outlined by Trease and Evans [23] for the presence of Alkaloid, saponins, glycoside, carbohydrates, flavonoids, tannis, and protein.

\section{Ethical Approval}

The principle of Laboratory animal care was followed. All animals have been examined and approved by the appropriate ethics committee.

Procedure: During the acquisition training, the platform was placed in the center of the northeast quadrant and each animal through the aid of a clean $70 \mathrm{cl}$ plastic container to minimize stress was placed in the Morris water maze and allowed to explore the apparatus for 4 times of 60 seconds (max) per day from a start position. Once the animal is placed in the pool, we start the timer and once it locates and mounts on the platform the timer were stopped. However, if the animal could not locate the platform within the 60 seconds, the animal was directed to the platform with the aid of a plastic container and once it mounts on the platform, it was allowed to explore the surrounding for 10secs. Afterwards, they were picked up and placed on their appropriate holding cage. The next mouse was then placed in the pool and same procedure was repeated. Each mouse completed 4 trials per day over 3days. This amounted for 12 trials for acquisition training.

Reversal Training Period Began on the $4^{\text {th }}$ day: In the reversal training, the invisible platform was moved to the opposite quadrant and new start position were taken. Similar procedures as in acquisition training were carried out during the reversal training. Each of the mice completed 4 trials per day for 3 days.

A probe Trial: The $7^{\text {th }}$ day was known as the probe trial. At this time, there was no escape platform in the maze. Each animal completed one trial of 60 seconds. Each animal was placed in the maze and allowed to explore the pool. The quadrant duration and the number of entry form the northeast and southwest quadrants were noted.

The visible platform task was conducted on day 8: The platform that was visible was placed in the Southwest quadrant of the pool. Similar procedure as in acquisition training and reversal training was carried out and mice completed 4 trials.

\section{Behavior Scored}

The behaviors scored during the Morris water maze were in acquisition training and reversal, visible platform test. These include:

a. Swim latency (time taken to locate and mount the platform)

b. Whereas during the probe trial, the duration in each quadrant were recorded (NE, SE, NW, and SW) including the annulus acquisition crossing.

\section{Statistical Analysis}

Values were shown as mean and \pm SEM (standard error of mean). Hypothesis testing method includes one way (ANOVA), followed by post hoc. $\mathrm{P}<0.05$ was considered statistical significance and $\mathrm{P}<$ 0.001 as highly significant respectively.

\section{Results}

\section{Behaviors Scored in The Morris Water Maze}

Acquisition Training: The swim latencies obtained on day 1,2 and 3 showed that mice, fed with control and Ibie leave diets, scored $163.75 \pm 16.31$ and $110.75 \pm 14.20$ seconds(day1); $73.50 \pm 6.50$ and $56.00 \pm 3.34$ seconds (day 2) and $92.25 \pm 13.57$ and $60.00 \pm 2.70$ seconds respectively(day3). The Ibie leave group swim latencies were statistically lower when compared to the group fed with the normal diet during the 3 days of training (Figure 1). 


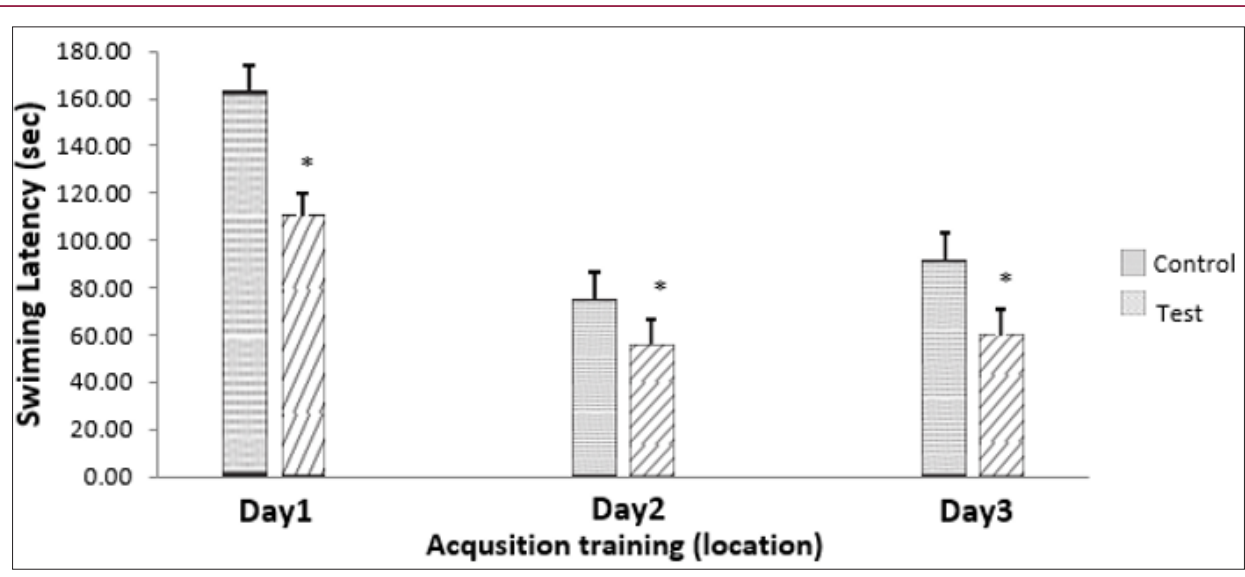

Note: * $p<0.05$ vs control

Figure 1: Swimming Latency during the acqusition training at day 1, day 2, and day 3, in the Maze training test. Values are expressed as mean $\pm \mathrm{SEM}, \mathrm{n}=9$.

Reversal Training: The swimming latencies during the reversal training for mice fed with normal diet and Ibie leave diet were $99.75 \pm 4.76$ and $50.75 \pm 13.75$ seconds (day 1); $56.25 \pm 8.36$ and $26.50 \pm 3.22$ seconds (day 2) and $53.75 \pm 6.53$ and $35.50 \pm 3.61$ seconds (day 3 ) respectively. The lbie leave group was statistically lower in terms of the swim latencies during the reversal training (Figure 2) when compared to the normal $(\mathrm{P}<0.01)$. However, the Ibie leave group was also statistically shorter $(\mathrm{P}<0.05)$ when compared to group fed with normal diet.

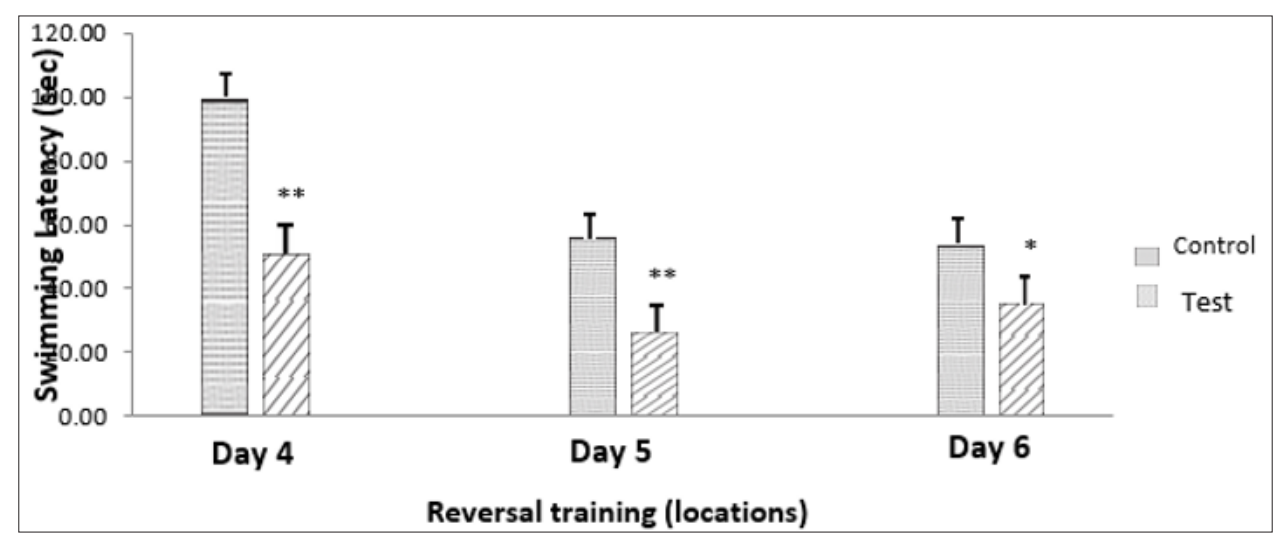

Note: ${ }^{* *} \mathrm{p}<0.01$ vs control ${ }^{*} \mathrm{p}<0.05$ vs control.

Figure 2: Swimming Latency during the reversal training at day 4, day 5 and day 6, in the Maze training test. Values are expressed as mean $\pm \mathrm{SEM}, \mathrm{n}=9$.

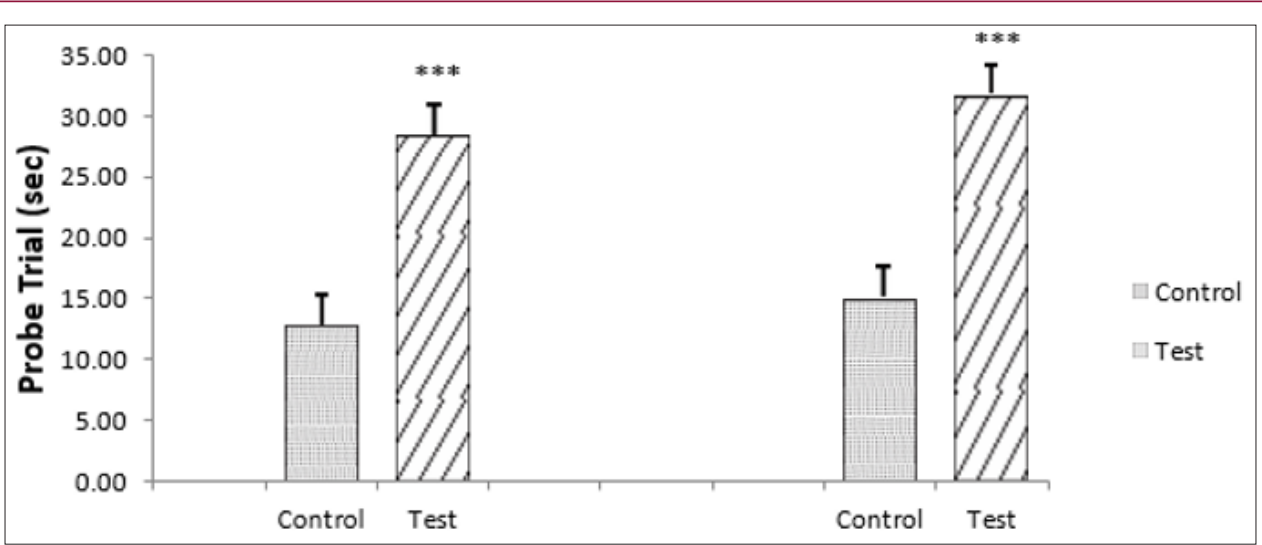

Note: *** $\mathrm{p}<0.001$ vs control.

Figure 3: Retention Quadrant during the Probe Trails during the Maze test. Values are expressed as meam \pm SEM, $n=9$. 
Retention Quadrant: The Retention quadrant between the two experimental groups of mice is $12.90 \pm 0.17$ and $28.52 \pm 2.63$ Secs). The preference to the NW and SE quadrant for the mice fed with
Ibie diets was statistically higher $(\mathrm{P}<0.001)$ compared to the group fed with normal diet (Figure 3).

\section{Annulus Acquisition \& Annulus Reversal Crossings}

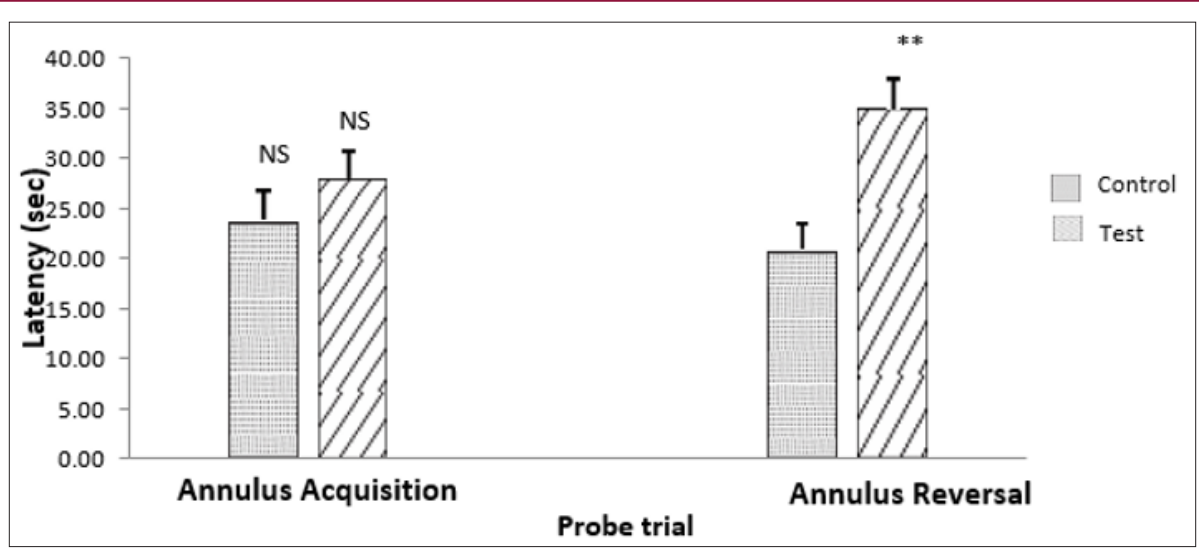

Note: ${ }^{* *} \mathrm{p}<0.01$ vs control.

Figure 4: Annulus Acquisition and Annulusreversal recorded at day 7 during the Maze test. Value are expressed as mean \pm SEM, $\mathrm{n}=9$.

The experimental values for the annulus acquisition crossings are $23.75 \pm 3.35$ and $51.66 \pm 12.57$ seconds for mice fed with control and Ibie diet respectively. The annulus reversal crossings values are $20.75 \pm 0.85$ and $35.00 \pm 4.26$ seconds for mice fed control and Ibie diet. Annulus acquisition crossings showed no significant difference among the groups. However, the Ibie leave group was statistically higher $(\mathrm{P}<0.01)$ compared to the normal group in annulus traversal crossings (Figure 4).

\section{Visible Platform Task}

In the visible platform task, the swim latency was $56.25 \pm 2.39$ and $32.00 \pm 2.85$ seconds for mice fed with control and diet. The Ibie group was statistically lower $(\mathrm{P}<0.001)$ compared to control in the visible platform task (Figure 5).

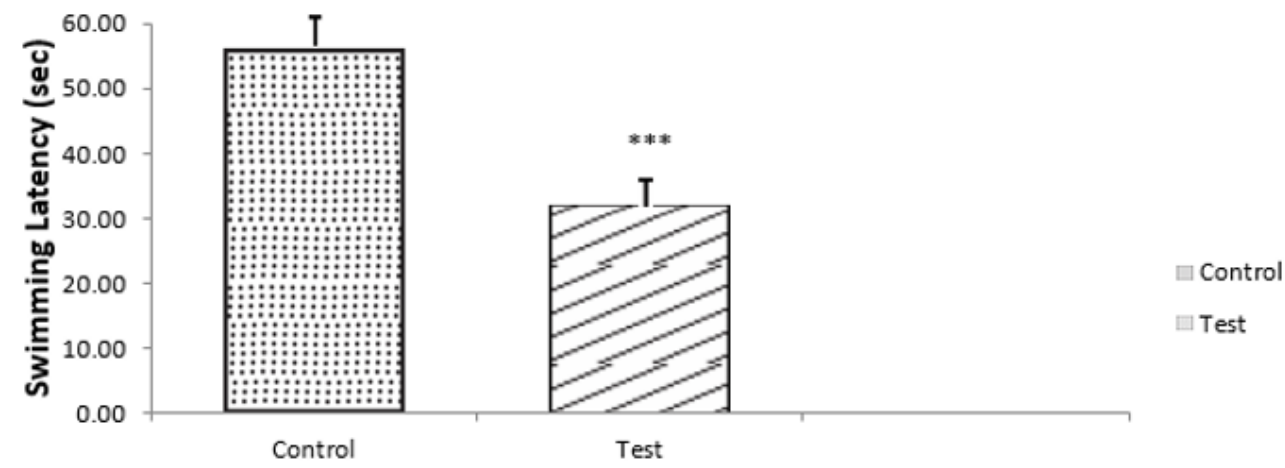

Visible Platform

Note: ${ }^{* * *} \mathrm{p}<0.001$ vs control.

Figure 5: Visible platform task recorded at day 8 during the Maze test. Values are expressed as meam \pm SEM, $n=9$.

\section{Discussion}

The maze apparatus was employed as a behavioral model for evaluation of spatial learning \& memory in CD-1 mice. This model is widely employed for assessing the effect of drugs on learning and memory (24). The results showed that increase in swim latency during acquisition training period as shown in Figure 1 shows that the Ibie leave fed mice which were the test group, learnt faster mounting the escape platform as compared to the group not fed with Ibie leave (control). Similarly, in the period of the reversal training, the test animals takes less time in locating the escape platform when compared to the group fed with normal diet. The experimental animals prefer the Northwest and Southeast (NW and SE) during the probe trial in the retention quadrant compared to control. Thus, indicating that these treated mice remembered the escape platform position located in the NW and SE quadrant compared to the group fed with normal diet, thus increasing their frequency to these quadrants for escape as compared to the control.

The result justifies that their memory was improved as compared to group fed with normal diet that had lesser preference to the retention quadrants. The test animals in the visible platform 
task, still showed shorter swim latency compared to their group fed with normal diet, suggesting that they have better memory. It has been reported that flavonoids have effect on memory and cognition. Although many studies in the field have been performed with flavonoid-rich foods, both these studies and studies with isolated flavonoids have potential to activate synaptic signaling and ability to improve cerebrovascular blood flow thus improve memory [25]. Studies with fruit supplements indicate that flaanols, tlavanones and anthocyanidins which are derivatives of flavonoid have the capacity to improve memory [26]. It has been reported, flavonoids have the potential to improve human memory and neuro-cognitive performance Jeremy P.E. Spencer. Therefore, flavonoid which is one of the major constituent of the Ibie leave may be responsible for the learning and memory enhancing activity exhibited by the experimental animal (mice).

\section{Conclusion}

The Ibie leave (Mucuna flagellipes) have been proven to have learning and memory enhancing effect. Therefore, the Ibie leave can be recommended for its good therapeutic efficacy for improving learning and memory, if it is extrapolated to humans.

\section{Acknowledgement}

The authors wish to acknowledge the assistance of Mr. Oreabosi Michael in collection of the sample and Mr.Uchenna who help in the laboratory analysis.

\section{References}

1. Okafor JC (1998) some useful tropical plants in health care delivery. Guest lecture Delivered at the 6th annual general meeting of the Nigeria society of pharmacognosy of 12 commonly used medicinal herbs. Archives of Family- Medicine 7: 523-536.

2. Borris RP (1996) Natural products research: perspectives from major Pharmaceutical Company. Journal of ethnopharmacology 51 (13): $29-38$

3. Drew T (1993) Motor cortical activity during voluntary gait modifications in the cat. I. Cells related to the forelimbs. Journal of Neurophvsiology 70(1): 179-82.

4. Rates SMK (2001) Tuvin 39: 603-13.

5. Elsenberg DM, Davis RB, Appel S, Wikey S, Kessler MRC (1998) Trends in Alternative Medicine in the United States. Journal of American Medicinal Association pp. 100-116.

6. Turrow V (1998) Herbal therapy for children. Pediatrics 102: 14921493.

ISSN: 2574-1241

DOI: 10.26717/BJSTR.2018.07.001442

Amah. Biomed J Sci \& Tech Res

(C) (i) This work is licensed under Creative (c) Commons Attribution 4.0 License

Submission Link: https://biomedres.us/submit-manuscript.php
7. Wild R (Ed) (1994) The complete book of natural and medicinal cures. Rodale Press, Inc Emmanus Pennyslvania New York, USA.

8. Bangori D (2003) What is traditional medicine world. World health organization (WHO) Media - centre. Evidence and mechanisms of action. Nutrition 130: 2127-2130.

9. Kafaru (1994) Cognitive function: a cross-sectional study from the Tsurugaya Project 1. American J Clin Nutr 83: 355-361.

10. Kains MG (2007) Guterbery book of culinary herbs, their cultivation, harvesting and curing uses. - Macmillana New York, USA, pp: 12-23.

11. Abbiw D (1990) Useful plants of Ghana Intermediate Technology. Botanical Garden Kew p. 337.

12. Rajaman N, Jonardhaman K (1991) The botanical composition and nutritional potential of the tribal pulse, Mucuna gigants (wild) DC plant food for human. Nutrition 4: 45-51.

13. Siddhuragu PK, Vijiayakumari, Jonardiam K (1996) Chemical composition and protein quality of little known legumes velvet (LDC). Journal of Agricultural and food chemistry 44(9): 2636-2641.

14. Houghton J (1994) Flora of West Africa 1: 10-15.

15. Thompson W (1978) Medicine from the earl company Maiden head, Mc Graw Hill book, United Kingdom.

16. Faridah HanumI, Van der Maesenh J (1996) Prosea handbooks No 1, auxiliary plants pros seal Bogor, Wagering, Netherlands, p. 16-17.

17. Murray VR, Johardhaman (1995) Chemical analysis and nutritional assessment of lesser known plants of the genus, Mucuna Food chemistry 52(3): 275-280.

18. Grieve M (2006) A modern herbal home. p. 6-10.

19. Nwude N (1986) Veterinary aspect of Medicinal plant. Macmillana New York, USA.

20. Okolo M, Unaiqual JE (1984) Herbal medicine: selected or potentiating herb interaction. Archives of internal medicine 158: 2200-2211.

21. Lesile S Cobley (1985) Introduction to the Botany of tropical Crops. K Longman Green and Co. Limited. Grosvenar Street London, UK, p. 48-56.

22. Farogi AA, Khan MM, Asundahara M (1999) Production technology of Medicinal and Aromatic crops Natural remedies pvt Ltd Bangalore India p. 26-29.

23. Trease GE, Evans WC (1989) Pharmacognosy (11 ${ }^{\text {th }}$ Edn.), Macmillian Publishers, London, UK

24. Morris R (1984) Developments of a water-maze procedure for studying spatial learning in the rat. J Neurosci Methods 11(1): 47-60.

25. Rendeiro C, Guerreiro JDT, Williams C, Spencer J (2012) Flavonoids as modulators of memory and learning: molecular interactions resulting in behavioral effects. Proceedings of the Nutrition Society 71(2): 246-262.

26. Sofowara EA (1982) Medicinal plants and traditional medicine in Africa, John Willey and sons, New York, USA, pp: 107-112.

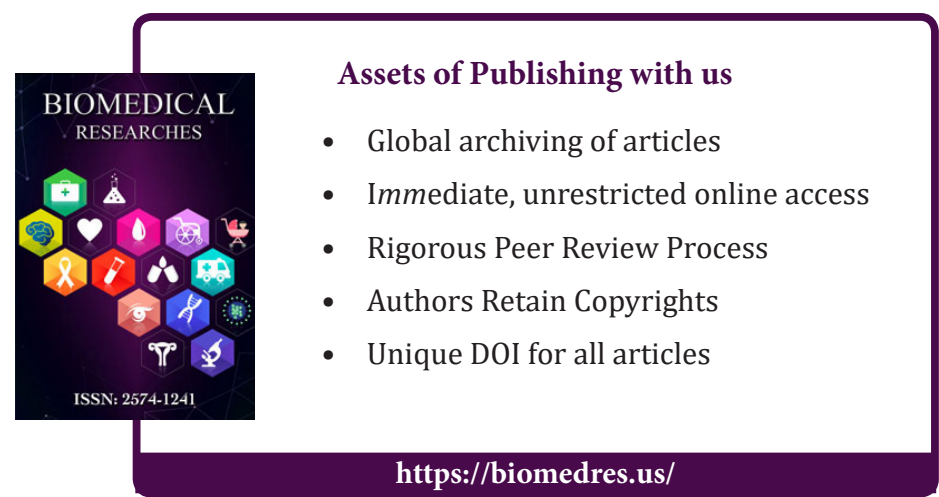

